FACTA UNIVERSITATIS

Series: Physical Education and Sport, Vol. 17, No 1, 2019, pp. 125 - 133

https://doi.org/10.22190/FUPES190425014Z

Research article

\title{
THE MOTOR ABILITIES OF HANDBALL PLAYERS OF DIFFERENT BIOLOGICAL MATURATION
}

\author{
UDC 796.322.012
}

\section{Mladen Živković, Nenad Stojiljković, Vladimir Antić, Ljubomir Pavlović, Nemanja Stanković, Bojan Jorgić}

Faculty of Sport and Physical Education, University of Niš, Serbia

\begin{abstract}
The aim of this research was to determine the differences between the results from the tests of motor abilities carried out on a selected group of handball players in relation to their biological maturation. A total of 23 handball players, belonging to a selected group, took part in this research. The overall sample of participants was divided into three groups based on their biological maturation. The measurements of motor abilities were carried out using the following tests: explosive power, sprint speed and rapid changes in direction. The statistical analysis included descriptive statistics, a univariate analysis of variance and the Bonferroni PostHoc test in order to determine whether a statistically significant difference could be detected between the groups on the tests of motor abilities. Based on the statistical analysis (ANOVA method), a difference was determined between the peak height velocity (PHV) groups for all the variables. The PostHoc test later determined that there were no differences for any of the variables between the PrePHV and MidPHV groups. Differences in all the variables were determined between the PrePHV and PostPHV groups. Differences between the MidPHV and PostPHV groups were determined for 7 variables, while no statistically significant difference was determined for 3 of the variables (5JT, T-test and the Slalom). The main contribution of this research is that it indicates to coaches the inevitability of being familiar with the biological maturation of their players for optimal selection, for adequate training design, and a decrease in the risk of injury.
\end{abstract}

Key words: $P H V$, explosive power, sprint, rapid changes in direction

Received April 25, 2019 / Accepted May 27, 2019

Corresponding author: Mladen Živković

University of Niš, Faculty of Sport and Physical Education, Čarnojevića 10a, 18000 Niš, Serbia

Phone: +381 18510900 •E-mail: profzile@ gmail.com 


\section{INTRODUCTION}

Handball is a sport in which the motor abilities of power, speed and agility, along with technical skills, represent important factors for the successful participation in sport at the elite level (Mohamed et al., 2009). In handball, as is in most sports involving younger categories of players, the male players who are biologically more mature have better anthropometric characteristics, greater body height and mass, and are superior in performing tasks which require speed and power (Matthys, Vaeyens, Coelho-e-Silva, Lenoir, \& Philippaerts, 2012). In studies which included handball players of both genders, of different categories and levels of competition, it was proven that the degree of maturation influences the level of performance between male and female players. This research has indicated that anthropometric characteristics represent a determining variable in the case of men when we take into consideration the level of competition, jump height, and endurance tests as the determinants of success for both genders (Fernández-Romero, Suárez, \& Cancela, 2016). Differences in maturation, accompanied by the method of determining Peak Height Velocity (PHV), anthropometry, and the physical performances of young handball players of various playing positions belonging three age groups (U14, U15 and U16) were determined for all the positions. Differences can be found between the playing positions in terms of degree of maturation, anthropometry, and the results on the tests of power, speed and agility (Matthys et al., 2013).

The individual differences among adolescents of the same chronological age in somatic and biological maturation are great. The evaluation of maturation is very important, both from the viewpoint of research, which focuses on adolescents, and also from the viewpoint of the selection process involving athletes. One of the non-invasive methods used to evaluate PHV based on anthropometric characteristics was confirmed on the level of two different samples. The research shows that males achieve their PHV at approximately 13.45 years of age, and girls at approximately 11.77 years of age (Mirwald, Baxter-Jones, Bailey, \& Beunen, 2002). Physical growth is the most important factor in the development of the physical response to exercise during childhood since it leads to an increase in physical performances as a result of biological maturation, in the form of changes in the muscular, nervous and endocrine system (Beunen \& Malina, 1988). The rate of growth is to a great extent responsible for the inter-individual differences in the physical performances of children of both genders (Rowland, 2005). The differences in the motor abilities can be even more intense if the children and adolescents are included in some organized form of physical exercise. The usual period of inclusion of children in sport is after the age of 12, when children usually opt for one sports game and the specialization of motor skills (Côté, Baker, \& Abernethy, 2003). One of the most popular sports games that children opt for at this age is handball, which is in accordance with the national popularity of this sport. The problem which emerges during this period is the composition of selected groups, where as part of one selection there is a great difference in the biological maturation of the players. Such heterogenous groups represent a problem in the development of motor abilities due to the different points in time when children enter the sensitive periods. The current research aims to indicate the inevitability of selection based on biological maturation so that the influence of the sports game on the development of the motor abilities of the players would be adapted to their level of biological maturation. The main aim of this research was to determine the 
differences in the results achieved on the tests of motor abilities of one selected group in relation to biological maturation.

\section{METHODS}

\section{The sample of participants}

They were all male handball players who were divided into three groups based on their biological maturation. The PrePHV group consisted of 6 participants (Age: 12,33 $\pm 0,77 \mathrm{yr}$; sports experience: $19.33 \pm 13.37$ months; Height: $159.33 \pm 11.26 \mathrm{~cm}$, body mass: $63.47 \pm 13.47 \mathrm{~kg}$; BMI: $24.87 \pm 2.97 \mathrm{~kg} / \mathrm{m}^{2}$ ), the MidPHV group which consisted of 7 participants (Age: $12.97 \pm 0.53 \mathrm{yr}$; sports experience: $32 \pm 15.62$ months; Height: $168.14 \pm 5.18 \mathrm{~cm}$, body mass: $71.57 \pm 9.93 \mathrm{~kg}$; BMI: $25.26 \pm 3.25 \mathrm{~kg} / \mathrm{m}^{2}$ ), and the PostPHV group which consisted of 10 participants (Age: 15.28 $\pm 1.18 \mathrm{yr}$; sports experience: $39.5 \pm 23.52$ months; Height: $176.02 \pm 8.84 \mathrm{~cm}$, body mass: $78.86 \pm 11.44 \mathrm{~kg}$; BMI: $25.5 \pm 3.74 \mathrm{~kg} / \mathrm{m}^{2}$ ). The participants voluntarily took part in this research which was carried out in accordance with the Declaration of Helsinki. Approval from the parents/guardians was obtained for all the participants, as during the course of this research they were under 18 (age rank: 11.5-17.3 years).

\section{The sample of variables}

Integral diagnostic procedures consist of the measurement and evaluation of the basic anthropological status of an individual, and specific abilities/characteristics and knowledge responsible for successful performance of technical-tactical elements in handball. Diagnostic procedures provide answers to questions about actual status; they initiate changes, motivate progress and finally confirm it (Gruić, Ohnjec, \& Vuleta, 2011).

\section{Anthropometric characteristics}

Anthropometric characteristics were measured while the participants were barefoot or dressed in their gym clothes (Đurašković, 2001). Measurements of body mass (kg) were carried out on electronic scales to within an $0.1 \mathrm{~kg}$ (Omron BF 511), measurements of body height, sitting height and leg length were carried out with an anthropometer to within an $0,1 \mathrm{~cm}$ (anthropometer according to Martin). The Body Mass Index (BMI) was calculated as the ratio between body mass in kilograms and squared body height in meters $\left(\mathrm{kg} / \mathrm{m}^{2}\right)$.

\section{The evaluation of maturation}

Biological maturation of the participants was calculated for each individual on the day when the motor abilities were tested, following the formula determined by Mirwald, Baxter-Jones, Bailey, \& Beunen (2002). The non-invasive method which evaluated PHV taking into consideration anthropometric characteristics (body height, sitting height, leg length) and chronological age. The division of the participants into a Pre-, Mid and PostPHV group was carried out in relation to the PHV. The PrePHV group included participants who would reach their PHV in 0.5 years or more. The participants who would reach PHV in from between -0.5 to 0.5 years were included in the MidPHV group. The PostPHV group included participants who reached their PHV 0.5 years ago or more (Meyers, Oliver, Hughes, Lloyd, \& Cronin, 2017). 


\section{Evaluation of explosive power}

Jumps are usually applied for the purpose of testing explosive power, due to the short duration and intensity of movement (Cormie, Mcguigan, \& Newton, 2011). In this research we used four tests for the evaluation of explosive power. Three tests were used to evaluate vertical jumping (Bosco, Luhtanen, \& Komi, 1983): the counter-movement jump (CMJ), the free arms counter-movement jump (CMJ free arms), the squat jump (SJ); to evaluate horizontal jumping (Chamari et al., 2008) the 5-jump test (5JT) was used. The participants performed three repetitions of each jump with $30 \mathrm{sec}$ pauses between each repetition and $5 \mathrm{~min}$ breaks between the performance of each individual test. The highest or longest jump of the three was taken as data for statistical analysis. The evaluation of vertical jumping was carried out on a flat surface using a system of electric photocells (Optojump, Microgate, Bolzano, Italy) which displayed excellent validity and reliability when testing these types of jumps (Glatthorn et al., 2011).

\section{Evaluation of speed}

The evaluation of the speed of the participants was carried out on the $5 \mathrm{~m}, 10 \mathrm{~m}$, and 20m sprint (Ellis et al., 2000). The participants performed three repetitions with 30s pauses between each repetition, while the fastest performance was included as data for the statistical analysis. A system of photocells (Witty, System, Microgate, Bolzano, Italy) was set at the starting line, at a distance of $5 \mathrm{~m}, 10 \mathrm{~m}$, and $20 \mathrm{~m}$ from the start, in order to measure lap time, along with an increase in speed. The system of photocells was set at hip height for all the participants so as to ensure that only one part of the participant's body passed through the gate (Yeadon, Kato, \& Kerwin, 1999). The test requires the maximal performance of the $20 \mathrm{~m}$ sprint. The participant assumes a high start position at $50 \mathrm{~cm}$ from the start line, and is instructed that the goal line is to be passed as soon as possible.

\section{The evaluation of agility}

The evaluation of agility was carried out using three tests: the T-test, Zig Zag and the Slalom (Mackenzie, 2005; Sporiš, Jukić, Milanović, \& Vučetić, 2010). The participants performed three repetitions of each test with $30 \mathrm{sec}$ pauses between each repetition and $5 \mathrm{~min}$ breaks between the performance of the various tests of agility. The fastest performance was included as data for the statistical analysis. Measurements of the results were carried out using a system of photocells (Witty, System, Microgate, Bolzano, Italy), while all of the equipment was set up according to the guidelines and recommendations of authors who worked with these systems of tracking results (Yeadon et al., 1999).

\section{Statistical analysis}

The statistical analysis included descriptive statistics, a univariate analysis of variance (ANOVA method) and the Bonferroni post-hoc test in order to determine whether there was a statistically significant difference between any of the groups on the tests of motor abilities. The level of statistical significance was set at $p<0.05$. All of the data were processed using the statistical package IBM SPSS (version 24.0; Inc., Chicago, IL, USA). 


\section{RESULTS}

Table 1 shows the results of the ANOVA which indicates the differences between the PHV groups (Pre, Mid and Post) in relation to the tests of motor abilities (CMJ, CMJ free arms, SJ, 5JT, 5m, 10m, 20m, the T-test, Zig Zag, Slalom). Based on the statistical significance (Sig.) it can be concluded that there is a difference between the PHV groups for all the tested motor abilities.

Table 1 The differences between the PHV groups in relation to the motor abilities (ANOVA method)

\begin{tabular}{|c|c|c|c|c|c|c|}
\hline Variable (unit) & & Sum of Squares & $\mathrm{df}$ & Mean Square & $\mathrm{F}$ & Sig. \\
\hline \multirow{3}{*}{$\mathrm{CMJ}(\mathrm{cm})$} & Between Groups & 639.43 & 2 & 319.71 & 9.71 & $0.00 *$ \\
\hline & Within Groups & 658.19 & 20 & 32.91 & & \\
\hline & Total & 1297.61 & 22 & & & \\
\hline \multirow{3}{*}{ CMJ free arms $(\mathrm{cm})$} & Between Groups & 1233.81 & 2 & 616.90 & 12.22 & $0.00 *$ \\
\hline & Within Groups & 1009.67 & 20 & 50.48 & & \\
\hline & Total & 2243.48 & 22 & & & \\
\hline \multirow{3}{*}{$\mathrm{SJ}(\mathrm{cm})$} & Between Groups & 345.83 & 2 & 172.91 & 6.14 & $0.01 *$ \\
\hline & Within Groups & 563.57 & 20 & 28.18 & & \\
\hline & Total & 909.39 & 22 & & & \\
\hline \multirow{3}{*}{$5 \mathrm{JT}(\mathrm{cm})$} & Between Groups & 15.86 & 2 & 7.93 & 4.09 & $0.03 *$ \\
\hline & Within Groups & 38.75 & 20 & 1.94 & & \\
\hline & Total & 54.61 & 22 & & & \\
\hline \multirow{3}{*}{$5 \mathrm{~m}(\mathrm{~s})$} & Between Groups & 0.07 & 2 & 0.04 & 5.73 & 0.01* \\
\hline & Within Groups & 0.12 & 20 & 0.01 & & \\
\hline & Total & 0.20 & 22 & & & \\
\hline \multirow{3}{*}{$10 \mathrm{~m}(\mathrm{~s})$} & Between Groups & 0.27 & 2 & 0.13 & 8.99 & $0.00 *$ \\
\hline & Within Groups & 0.30 & 20 & 0.01 & & \\
\hline & Total & 0.57 & 22 & & & \\
\hline \multirow{3}{*}{$20 \mathrm{~m}(\mathrm{~s})$} & Between Groups & 1.12 & 2 & 0.56 & 12.51 & 0.00* \\
\hline & Within Groups & 0.89 & 20 & 0.04 & & \\
\hline & Total & 2.01 & 22 & & & \\
\hline \multirow{3}{*}{ T-test (s) } & Between Groups & 13.19 & 2 & 6.59 & 6.64 & $0.01 *$ \\
\hline & Within Groups & 19.85 & 20 & 0.99 & & \\
\hline & Total & 33.04 & 22 & & & \\
\hline \multirow{3}{*}{ Zig Zag (s) } & Between Groups & 2.49 & 2 & 1.25 & 9.87 & $0.00 *$ \\
\hline & Within Groups & 2.52 & 20 & 0.13 & & \\
\hline & Total & 5.01 & 22 & & & \\
\hline \multirow{3}{*}{ Slalom (s) } & Between Groups & 3.90 & 2 & 1.95 & 3.89 & 0.04* \\
\hline & Within Groups & 10.02 & 20 & 0.50 & & \\
\hline & Total & 13.92 & 22 & & & \\
\hline
\end{tabular}

Table 2 shows the results of the means (Mean) and standard deviation (SD) for each variable in relation to the PHV group. The results of the PostHoc test (Sig.) indicate between which groups a statistically significant difference was determined for the tests of motor abilities. 


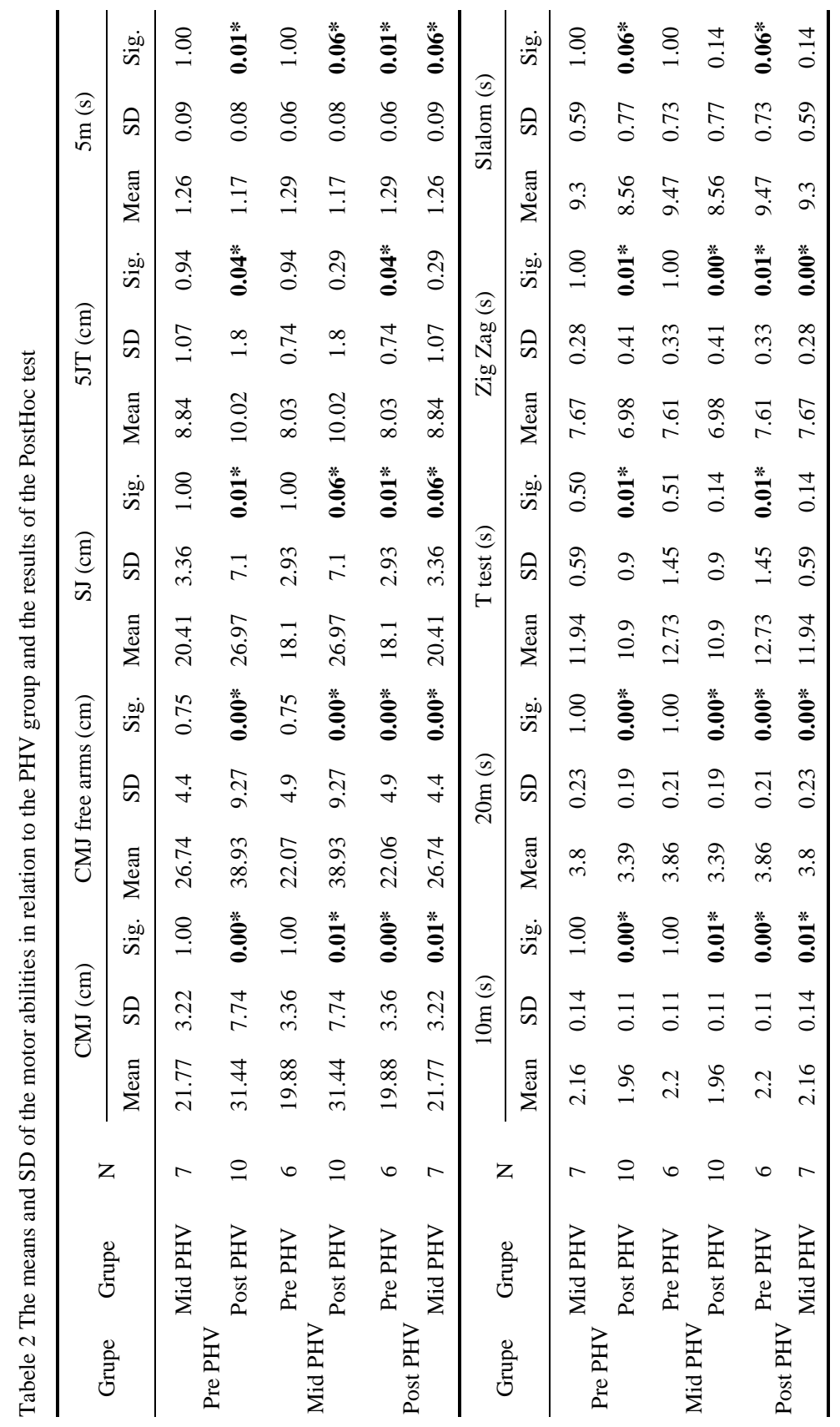


Based on the results shown in table 2 we can conclude that there is no statistically significant difference between the PrePHV group and MidPHV group on any of the tests of motor abilities. A statistically significant difference was determined between the PrePHV group and PostPHV group on all the tests of motor abilities: CMJ (Sig.=0.00), CMJ free arms (Sig.=0.00), SJ (Sig. $=0.01), 5 J T$ (Sig. $=0.04), 5 \mathrm{~m}($ Sig. $=0.01), 10 \mathrm{~m}($ Sig. $=0.00), 20 \mathrm{~m}$ (Sig. $=0.00)$, the T test $($ Sig. $=0.01)$, Zig Zag (Sig.=0.01), Slalom (Sig.=0.01). Better results were achieved by the PostPHV group. Differences in the results of the tests of motor abilities were found between the MidPHV group and PostPHV group for the following variables: CMJ (Sig.=0.01), CMJ free arms (Sig. $=0.00$ ), SJ (Sig. $=0.06$ - borderline significant), $5 \mathrm{~m}$ (Sig. $=0.06$ - borderline significant), $10 \mathrm{~m}$ (Sig. $=0.01), 20 \mathrm{~m}$ (Sig. $=0.00), \mathrm{Zig}$ $\mathrm{Zag}$ (Sig.=0.01). Better results were achieved by the PostPHV group. Based on the obtained results we can conclude that the PostPHV group dominates this selected group.

\section{DISCUSSION}

The aim of this research was to determine the differences in the achieved results for motor abilities of a selected group of handball players in relation to their biological maturation. Table 1 (ANOVA) shows the differences in the achieved results on the tests of motor abilities between all three PHV groups of participants. Based on the level of statistical significance, it can be concluded that there is a difference in the achieved results in all the variables. In order to determine between which of the groups a difference could be found, the PostHoc test was carried out (table 2).

It has already been stated that the main characteristics of taking part in the game of handball were well-developed power, speed and agility (Mohamed et al., 2009). In order to measure these abilities, primarily tests of jumping, the sprint, and rapid changes in direction were used. Jumping represent a complex multi-joint movement from which we obtain external mechanical power as the product of the foot pushing against the surface, which is usually used to test explosive power (Finni, Komi, \& Lepola, 2000; Cormie et al., 2011). This research determined that there were no differences between the PrePHV and MidPHV group in the achieved results for the tests of explosive power (table 2), that is, that the PrePHV and PostPHV group differ on all the tests, a and that a difference between the MidPHV and the PostPHV group was not found for only one test (5JT). Speed was tested using the sprint which is connected to shorter contact time between the foot and surface and is directly related to the ability of muscle-tendon units to perform a rapid cyclical contraction (Young, Mc Lean, \& Ardagna, 1995). Early acceleration is connected to longer contact time between the foot and the surface and depends on the contractile forces (Mero, 1988). This research indicates that there is no difference between the PrePHV and MidPHV group in the results for the tests of speed (table 2), that is, that there is a difference between the PrePHV and PostPHV group for all the tests. The tests of agility evaluate the ability to rapidly change direction without a decrease in speed (Semenick, 1990). The results of this research indicate that there is no difference in the achieved results on the tests of agility (table 2) between the PrePHV and MidPHV group, that is, that there is a difference between the PrePHV and PostPHV group on all the tests, while differences exist between the MidPHV and PostPHV group for only one test (Zig $\mathrm{Zag}$ ). The reason behind these results can be found in the sensitive periods of the development of motor abilities which occur during adolescence, as a period of time 
especially sensitive to the training process (Balyi \& Way, 2005). The results of this research match those of the study carried out by Matthys et al. (2012) which aimed to explain the variations between motor peformances in terms of chronological age, biological maturation, training, and anthropometry on a sample of 168 handball players. The results indicated that differences in motor performances can be found in relation to the type of PHV group, that is, that the participants who belong to the PostPHV group achieved the best results on the applied tests, which is fully in agreement with the current research.

\section{CONCLUSION}

Taking part in handball requires well-developed motor abilities, primarily power, speed and agility. This sports game, in addition to indicating the inevitability of well-developed motor abilities (power, speed and agility), also with its specific nature influences their development, as this study has confirmed. The research results indicate the inevitability of selecting players based on their biological maturation, and not their chronological age. There is a clear difference in power, speed and agility between the PrePHV and PostPHV group, as well as between the MidPHV and PostPHV group. Based on these data we can conclude that one selection could be made up of players who belong to the PrePHV and MidPHV group of biological maturation, while the players who belong to the PostPHV group would have to make up another selected group. This type of selection is needed so that the groups would be homogenous in terms of motor status, and in order to make use of the sensitive period which is most susceptible for the development of motor abilities. The main contribution of this research is that it indicates to the coaches that they must know the biological maturation of their players in order to perform optimal selection, to design an adequate training program, and to reduce the possible risk of injury.

\section{REFERENCES}

Balyi, I., \& Way, R. (2005). Canadian sport for life: Long-Term athlete development resource paper. Vancouver, BC: Canadian Sport Centres.

Beunen, G., \& Malina, R. M. (1988). Growth and physical performance relative to the timing of the adolescent spurt. Exercise and Sport Sciences Reviews, 16(1), 503-540.

Bosco, C., Luhtanen, P., \& Komi, P. V. (1983). A simple method for measurement of mechanical power in jumping. European Journal of Applied Physiology and Occupational Physiology, 50(2), 273-282

Chamari, K., Chaouachi, A., Hambli, M., Kaouech, F., Wisløff, U., \& Castagna, C. (2008). The five-jump test for distance as a field test to assess lower limb explosive power in soccer players. The Journal of Strength \& Conditioning Research, 22(3), 944-950.

Cormie, P., Mcguigan, M.R., \& Newton, R.U. (2011). Developing maximal neuromuscular power: part 2 training considerations for improving maximal power production. Sports Medicine, 41(2), 125-146.

Côté, J., Baker, J., \& Abernethy, B. (2003). From play to practice: A developmental framework for acquisition of expertise in team sports. In J.L. Starkes \& K.A. Ericsson (Eds.), Expert performance in sports (pp. 89113). Champaign, IL: Human Kinetics.

Đurašković, R. (2001). Biologija razvoja čoveka sa medicinom sporta (Biology of human development with sports medicine). Niš: S.I.I.C. In Serbian

Ellis, L., Gastin, P., Lawrence, S., Savage, B., Buckeridge, A., Stapff, A., et al. (2000). Protocols for the physiological assessment of team sport players. In C. Gore, Physiological tests for elite athletes (pp. 128144). Champaign, Illinois: Human Kinetics.

Fernández-Romero, J.J., Suárez, H.V., \& Cancela, J.M. (2016). Anthropometric analysis and performance characteristics to predict selection in young male and female handball players. Motriz: Revista de Educação Física, 22(4), 283-289. 
Finni, T., Komi, P.V., \& Lepola, V. (2000). In vivo human triceps surae and quadriceps femoris muscle function in a squat jump and counter movement jump. Europen Journal of Applied Physiology, 83, 416-426.

Glatthorn, J.F., Gouge, S., Nussbaumer, S., Stauffacher, S., Impellizzeri, F.M., \& Maffiuletti, N.A. (2011). Validity and reliability of Optojump photoelectric cells for estimating vertical jump height. The Journal of Strength \& Conditioning Research, 25(2), 556-560.

Gruić, I., Ohnjec, K., \& Vuleta, D. (2011). Comparison and analyses of differences in flexibility among toplevel male and female handball players of different ages. Facta Universitatis Series Physical Education and Sport, 9(1), 1-7.

Mackenzie, B. (2005). Performance evaluation tests. London: Electric World plc.

Matthys, S. P., Fransen, J., Vaeyens, R., Lenoir, M., \& Philippaerts, R. (2013). Differences in biological maturation, anthropometry and physical performance between playing positions in youth team handball. Journal of Sports Sciences, 31(12), 1344-1352.

Matthys, S.P.J., Vaeyens, R., Coelho-e-Silva, M.J., Lenoir, M., \& Philippaerts, R. (2012). The contribution of growth and maturation in the functional capacity and skill performance of male adolescent handball players. International Journal of Sports Medicine, 33(7), 543-549.

Mero, A. (1988). Force-time characteristics and running velocity of male sprinters during the acceleration phase of sprinting. Research Quarterly for Exercise and Sport, 59(2), 94-98.

Meyers, R.W., Oliver, J.L., Hughes, M.G., Lloyd, R.S., \& Cronin, J.B. (2017). Influence of age, maturity, and body size on the spatiotemporal determinants of maximal sprint speed in boys. Journal of Strength and Conditioning Research, 31(4), 1009-1016.

Mirwald, R.L., Baxter-Jones, A.D., Bailey, D.A., \& Beunen, G. P. (2002). An assessment of maturity from anthropometric measurements. Medicine \& Science in Sports \& Exercise, 34(4), 689-694.

Mohamed, H., Vaeyens, R., Matthys, S., Multael, M., Lefevre, J., Lenoir, M., et al. (2009). Anthropometric and performance measures for the development of a talent detection and identification model in youth handball. Journal of Sports Sciences, 27(3), 257-266.

Rowland, T.W. (2005). Children's Exercise Physiology. 2nd Edition. Champaign Il: Human Kinetics Book.

Semenick, D. (1990). Tests and measurements: The T-test. Strength \& Conditioning Journal, 12(1), 36-37.

Sporiš, G., Jukić, I., Milanović, L., \& Vučetić, V. (2010). Reliability and factorial validity of agility tests for soccer players. The Journal of Strength \& Conditioning Research, 24(3), 679-686.

Yeadon, M.R., Kato, T., \& Kerwin, D.G. (1999). Measuring running speed using photocells. Journal of Sports Sciences, 17(3), 249-257.

Young, W., Mc Lean, B., \& Ardagna, J. (1995). Relationship between strength qualities and sprinting performance. Journal of Sports Medicine and Physical Fitness, 35(1), 13-19.

\section{MOTORIČKE SPOSOBNOSTI RUKOMETAŠA RAZLIČITE BIOLOŠKE ZRELOSTI}

Cilj ovog istraživanja je da se utvrde razlike u ostvarenim rezultatima u testovima motoričkih sposobnosti rukometaša jedne selekcione grupe u odnosu na biološku zrelost. Ukupno 23 rukometaša, jedne selekcione grupe, učestvovalo je u ovom istraživanju. Celokupan uzorak ispitanika podeljen je u tri gupe prema biološkoj zrelosti. Merenje motoričkih sposobnosti rađeno je testovima: eksplozivne snage, sprinta i brze promene pravca. Statistička analiza obuhvatila je deskriptivnu statistiku, univarijantnu analizu varijanse i Bonferoni PostHoc kako bi se utvrdilo između kojih grupa postoji statistički zanačajna razlika u testovima motoričkih sposobnosti. Na osnovu statističke analize (ANOVA) utvrđeno je da postoje razlike između PHV grupa u svim varijablama. PostHoc testom je naknadno utvrđeno da razlike ne postoje ni u jednoj varijabli kada se porede PrePHV i MidPHV grupe. Poređenjem PrePHV i PostPHV grupe utvrđeno je da razlike postoje u svim varijablama. Razlike između MidPHV i PostPHV grupa pronađene su u 7 varijabli, dok u 3 varijable (5JT, T-test $i$ Slalom) ne postoji statistički značajna razlika. Glavni doprinos ovog istraživanja je što ukazuje trenerima na neminovnost poznavanja biološke zrelosti igrača kako bi izvršili optimalnu selekciju, odradili adekvatnu postavku treninga $i$ smanjili opasnost od eventualnog povređivanja.

Ključne reči: PHV, eksplozivna snaga, sprint, brza promena pravca 